$\operatorname{cocos},(1984) 2,44: 47$

Printed in Sri Lanka

Research Note :

\title{
Effect of extraction of inflorescence sap and the removal of immature fruit bunches on the production of female flowers in coconut
}

\author{
D.T. MATHES
}

\section{N T R O D U CTION}

Inflorescence sap is extracted from unopened spathes. This sap is commonly referred to as toddy and the process of stimulating the spathe to yield sap is referred to as tapping. Spathes, 6 to 8 weeks after emergence, are selected for tapping. Generally a palm is tapped for a period of 8 to 9 months continuously. All the inflorescences produced during this period are tapped. It is generally believed that after a spell of tapping, palms show a marked improvement in their nut production. This relationship has not been investigated. Hence this preliminary study was made to quantify the effect of tapping on female flower production.

Bunches of unripe coconuts are often harvested, as the nut water of these tender fruits is consumed as a beverage. Fruits at this stage of development, about 6 to 8 months after pollination, are referred to as Kurumba. The effect of removal immature bunches on the production of female flowers was also studied.

\section{MATERIALS AND METHODS}

\section{Effect of Tapping}

A blöck of palms, which had been rested for nearly an year after a spell of tapping, was selected for this study. The mean yield of this block prior to tapping was low, about 20 . nuts per palm per year. In each palm an inflorescence which had just opened, and the 2 monthold and 4 month-old fruit bunches, were marked. The number of female flowers in the florescence and the number. of developing fruits in the fruit bunches were courted. These counts weres taken as being representative of the progress of the development of the female flowers during the first four months. Development beyond 4 months was not recorded as Abeywardena \& Mathes (1971) has shown that the fruit drop after 4 months is negligible. A sample of 166 palms were studied. 
For. comparison, similar data was recorded on palms in high yielding and. very high yielding blocks, which had not been subjected to tapping; the yields of these blocks were approximately 65 and 90 . nuts per palm per year, respectively.

2. Effect of removal of immature bunches.

This experiment was carried out. on mature palms, to observe the effect of removal of immature fruit bunches on the production of female flowers in subsequent inflorescences. The following six treatments were tested : (i) Control, palms left to flower and fnit normally (2) removal of 4 months old fruit bunches; (3) removal of 5 months ald fruit bunches; (4) removal of 6 months old fruit bunches ;(5) removal of 7 months old fruit bunches;.(6) removal of 8 months old fruit bunches. The fruit bunches were removed for a period of 9 months, at monthly intervals. The number of female flowers on the inflorescences produced there after were counted.

\section{RESULTSAND DISCUSSION}

\section{Effect of Tapping}

It is evident from the results presented in Table 1 that the female flower production in tapped palms is much greater than in untapped palms. Low yielding palms, after tapping. produced 48 female flowers per inflorescence whereas the untapped high yielding and very high yielding palms had only 16 and 20 female flowers per inflorescence, respectively As the per-

Table 1 : Effect of tapping on the Production of Fenale Flowers and Fruits

Treatment Number of female flowers/developing fruits per bunch

at opening of at end of at end of
inflorescence two months four months

\begin{tabular}{|c|c|c|c|}
\hline Tapped low yielding palms (A) & 48 & 42 & 17 \\
\hline Uptapped very high yielding palms'(B) & 20 & 16 & 8 \\
\hline Untapped, high yielding palms (C) & 16 & 12 & 6 \\
\hline " $t$ " values to compare $A$ vs $B$ & $6.46^{* * *}$ & $5.32 * * *$ & $5.18^{* * * *}$ \\
\hline B vs C & $4.73 * *$ & $4.21 * *$ & $2.22 *$ \\
\hline
\end{tabular}




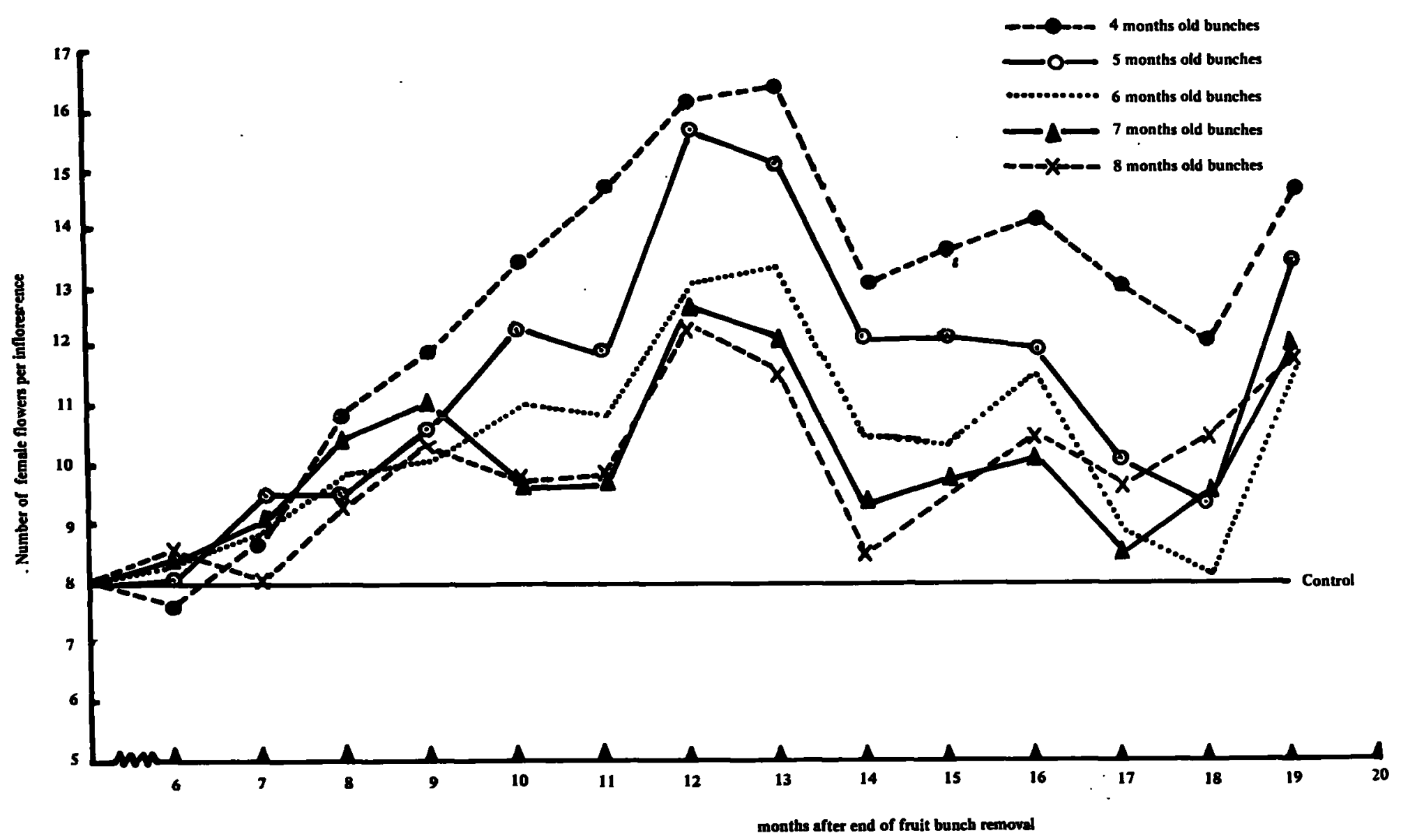




\section{D.T. MATHES}

centage fruit set was of the same order in tapped and untapped palms, the number of developing fruits per bunch in the tapped palms was also much greater at the end of 4 months. The number of female flowers at opening of inflorescence, and fruits at the end of 4 months in tapped palms is about thrice that of the high yielding palms and double that of the very high yielding untapped palms. Abeywardena and Mathes (1971) has shown that fruit drop after 4 months is negligible. The tapped palms would therefore be also expected to have a higher yield of mature nuts.

Effect of Removal of Immature Bunches.

The results are presented in Fig. 1. To facilitate comparison, the data has been adjusted so that the number of female flowers per inflorescence in the control is a constant.

In general, the thinning of fruit bunches has increased the production of female flowers. The increase during the first six months after thinning was negligible. But from then onwards the production increased steadily and reached a peak in the 12th month. A decreasing trend is evident over the next 6 months. (12th to 18 th months)

Removal of 4 months old fruit bunches had the greatest effect on female flower production, and produced twice the number in the control during the 12th month after thinning. As the age of the fruit bunch removed increased there was a progressive reduction of the effect on female flower production.

The preliminary studies indicate that injury to inflorescences or the removal of other reproductive stages stimulate the production of female flowers. Further experimentation to study this phenomenon is in progress.

\section{ACKNOWLEDGEMENTS}

My sincere thanks to Dr. U. Pethiyagoda former Director and Mr. V. Abeywardene former Biometrician Coconut Research Institute of Sri Lanka for the initiation of these studies. Further thanks to Dr. D.T. Wettasinghe Director, Coconut Research Institute for guidance in the preparation of the script. Thanks are also to officers of the Biometry Unit of the Coconut Reaserch Institute for helping in the collection of the Data and Mr. Ranjith Fernando for drawing the graph. Further thanks to Mrs. D.M.T. Marasinghe for typing the script.

\section{R E F E R E N C E S}

Abeywardene. V. and Mathes, D.T. (1971). Crop losses in coconut through buttun shedding and immature nutfall. Cey. Plrs, Rev. 6, 97-106. 